\title{
ILLEGAL LABELING AND THE ABUSE OF HALAL CERTIFICATE: CASE STUDY OF MALAYSIA
}

\author{
Rokshana Shirin Asa ${ }^{1}$
}

\begin{abstract}
In a culturally diverse country like Malaysia, halal logo plays an important role for Muslims to differentiate between halal and haram under the purview of Shariah principles. Product labeling provides a variety of choices to the consumers, contributing towards the value and usefulness of the products. The general thoughts of a consumer about food labeling are information about specific characteristics and the identification of food products with certified quality. However, halal labeling is a contemporary phenomenon and getting halal food itself is a challenging task. On the other hand, it is not easy to investigate the product once the food is packed. As a result, the Muslims depend on the responsible authority to check the status of halal and harmful products. Nevertheless, implementing halal certification in Malaysia is a voluntary act that creates some issues with illegitimate and unlawful use of the halal logo and halal certificate. That action impinges on the sensitivity of Muslim consumers in Malaysia and therefore, they may hesitate to buy or have doubt in selecting food and other goods for their consumption. This article describes some of the important issues regarding halal logo, explores the governments initiatives taken to expand the laws regarding the
\end{abstract}

Lecturer, Department of Business Administration, BGMEA University of Fashion \& Technology, Nishatnagor, Turag, Dhaka 1230, Bangladesh, rokshanashirin@ buft.edu.bd 
logo, the case study of the dilemma in issuing the halal logo as well as criminal liabilities and how illegal labeling violates the Muslim consumers' rights. In addition, it aims at drawing attention to policy-makers of necessary steps to improvise halal standard governance in Malaysia.

Keywords: Malaysia, illegal labeling, abuse of halal certificate, halal logo, Muslim consumers'rights, Malaysia

\section{INTRODUCTION}

Being a Muslim, the consumption of halal-labeled food is a rudimentary qualifying condition for developing, maintaining and reinforcing an overall Islamic lifestyle, identity and a mechanism for comforting stability. ${ }^{2}$ Islamic beliefs go beyond all acts of life, providing Malaysian Muslims with a set of resources and they are ideal for identity creation in a multicultural context. Moreover, Muslims want to guarantee that the food they consume has adhered to Shariah principles together with wholesome and good characteristics ${ }^{3}$ (tayyib). The reason that is why one should consume halal goods prohibits the haram and avoids doubtful things. Hence, in the case of halal food products' labeling or halal certificate that gives the perception to the Muslim consumers that the foods are produced according to the Shariah principles and standards. Halal labeling is an explicit mark on foodstuffs that add significance to the products. ${ }^{4}$ It guarantees acquiescence not only to Shariah requirements but also with other quality standards. Moreover, the halal logo is the symbol of confidence and trust. The majority of Muslim consumers in Malaysia are concerned about halal food and the halal logo on food products. ${ }^{5}$

The word 'halal' in whatever form, when displayed on products and premises has a special attraction to Muslim consumers in Malaysia. They believe that the halal issue is not just about the logo that is being used by the

2 Jamal, Ahmad \& Juwaidah Sharifuddin, 'Perceived Value and Perceived Usefulness of Halal Labeling: The Role of Religion and Culture,' Journal of Business Research, vol. 68/5 (2015): 933-941.

3 Tieman, Marco, 'Establishing the Principles in Halal Logistics,' Journal of Emerging Economies and Islamic Research, vol. 1/1 (2013).

4 Malkawi, Bashar H., 'Food Labeling and Halal Mark,' Intellectual Property Rights: Open Access (2014).

5 Borzooei, Mahdi \& Maryam Asgari, 'The Evolution of Halal from A Religious Symbol to A Brand,' Czech Journal of Social Sciences, Business and Economics, vol. 3/1 (2014): 48-56. 
food producers but it covers the total quality control measures involved in the monitoring of the slaughtering, handling and storage processes of the animals, as well as all the ingredients used in preparing the food products. Evidence also expose that both types of consumers Muslims and non-Muslims, respond more positively to halal logo. ${ }^{6}$

Furthermore, most consumers are able to differentiate the Malaysian halal logo from other countries' halal logo. ${ }^{7}$ Various socio-economic and attitude factors such as degree of awareness, trustworthiness, safety and health consciousness, government involvement and manufacturing practices and lastly, confidence with halal logo increase the consumers' confidence on JAKIM's halal logo. ${ }^{8}$ The religious concern and safety concept is associated with Muslims consuming halal food ${ }^{9}$ and in addition to that, consumers are very sensitive towards halal information that might result in loss of their confidence which in future might affect their intended purchasing decisions. ${ }^{10}$

From the very beginning, when JAKIM introduced their authorized halal logo, it had spawned more awareness among the Muslims. That accelerated the Muslim consumers to consume halal products or engage in services that follow Shariah guidelines and principles. The halal logo also certifies food outlets which are permissible to be occupied by Muslims. The purpose of this certification is to indicate that their products meet the Shariah requirements. This indirectly creates noteworthy benefits to the particular manufacturers that have halal labeling certification as opposed to their opponents that do not own halal certification.

6 Mathew, Vloreen Nity, 'Acceptance on Halal Food among Non-Muslim Consumers,' Procedia-Social and Behavioral Sciences, vol. 121 (2014): 262-271; Rezai, Golnaz, Zainalabidin Mohamed \& Mad Nasir Shamsudin, 'Assessment of Consumers' Confidence on Halal Labelled Manufactured Food in Malaysia,' Pertanika Journal of Social Science \& Humanity, vol. 20/1 (2012): 33-42.

7 Ambali, Abdul Raufu \& Ahmad Naqiyuddin Bakar, 'Halal Food and Products in Malaysia: People's Awareness and Policy Implications,' Intellectual Discourse, vol. 21/1 (2013): 7.

8 Rezai, Golnaz, Zainalabidin Mohamed \& Mad Nasir Shamsudin, 'Assessment of Consumers' Confidence on Halal Labelled Manufactured Food in Malaysia,' 3342.

9 Ambali, Abdul Raufu \& Ahmad Naqiyuddin Bakar, 'People's Awareness on Halal Foods and Products: Potential Issues for Policy-Makers,' Procedia-Social and Behavioral Sciences, vol. 121 (2014): 3-25.

10 Rezai, Golnaz, Zainalabidin Mohamed \& Mad Nasir Shamsudin, 'Assessment of Consumers' Confidence on Halal Labelled Manufactured Food in Malaysia,' 3342. 
In Malaysia, halal food products are effortlessly available and stress-free to gain. ${ }^{11}$ Halal food demands are rising although the consumers are being cheated with non-halal products and in the wrong labeling of the products which raise the sensitivity of Muslims in this country. However, it is not easy to investigate the product once the food is packed. As a result, the Muslims depend on the responsible authority to check the status of halal and harmful products. Nevertheless, holding the halal certificate in Malaysia is a voluntary act that creates some problems with illegitimate and unlawful use of the halal logo and halal certificate. That action impinges on the sensitivity of Muslim consumers in Malaysia and therefore, they may hesitate to buy or have doubt in selecting food and other goods for their consumption.

This chapter describes some of the important issues regarding halal logo, explores the governments initiatives taken to expand the laws regarding the logo, the case study of the dilemma in issuing the halal logo as well as criminal liabilities and how illegal labeling violates the Muslim consumers' rights. . In addition, to draw attention to policy-makers to take the necessary step to make more standard halal governance in Malaysia.

\section{GOVERMENT INITIATIVES FOR THE EXPANSION OF LAWS REGARDING HALAL LOGO IN MALAYSIA}

Halal logo was first presented by the Department of Islamic Development Malaysia (JAKIM) in charged by the Prime Minister's Department in 1994. ${ }^{12}$ Under the strict direction of JAKIM with mutual assistance from academicians, halal logo and halal certificate have been approved. The main purpose of this department is to make sure that foods, beverages, pharmaceutical products, cosmetics and other products that are granted the halal logo fulfil the requirements of Shariah principles and laws. ${ }^{13}$ Getting halal logo and halal certificate can be time-consuming and completion of the procedure also takes time for approval.

11 Market Watch, 'The Malaysian Food Industry,' http://www.malaysia.ahk.de/ fileadmin/ahk_malaysia/Market_reports/The_Malaysian_Food_Industry.pdf, accessed on 30 August 2016.

12 Halal Malaysia Official Portal, 'Halal History,' http://www.halal.gov.my, accessed on 12 August 2016.

13 Halal Malaysia Official Portal, 'Malaysian Halal Certification Procedure Manual,' http://www.halal.gov.my/v4/index.php/my/garis-panduan/manual-prosedurpensijilan-halal-malaysia, accessed on 14 July 2016. 
However, the prime laws on halal logo concerning food products can be principally found in the two regulations made under the Act, namely the Trade Descriptions (Use of Expression Halal Order) 1975 and the Trade Descriptions (Marking of Food) Order 1975. The effective enforcement of the above halal regulations together with the main Act were replaced by the TDA 2011, Trade Description (Definition of Halal) Order 2011 and the Trade Description (Certification and Marking of Halal) Order 2011 covering specific legal provision on matters relating to halal. The following are features of the Malaysia halal logo:

Figure 1: Features of the Malaysia Halal Logo

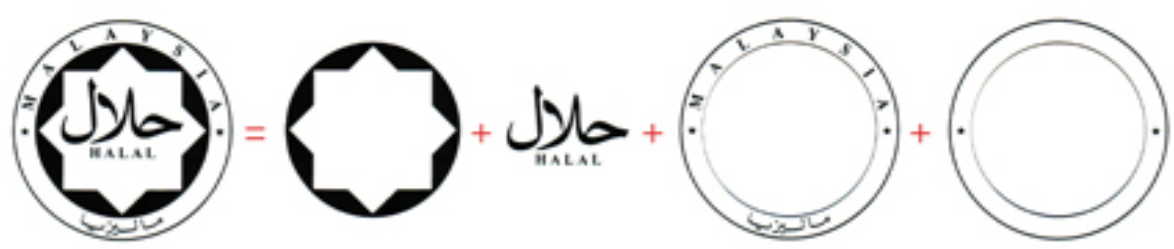

Halal logo refers to the logo issued by JAKIM/ JAIN/ MAIN and contains:

a) An eight-cusp star at the center of a circle.

b) The Arabic word "ححلآل" at the center of the star.

c) The word "HALAL" in Roman alphabets below it.

d) The word "Malaysia" written in Roman alphabets and ماليزيا in Arabic within the circle of the logo.

e) Two small five-cusp stars are positioned to separate the Roman alphabets from the Arabic word mentioned.

In addition, the definition of halal certification and the marking with halal under Sections 3 and 5 of the Trade Description (Certification and Marking of 'Halal') Order, 2011, Certification of 'halal' means:

"(1) All food, goods or services in relation to the food or goods, shall not be described as "halal" except:

a) It is certified as halal by the competent authority; and

b) It is marked with a logo as specified in Schedule 1.

(4) For the purpose of this Order, "services in relation to the food or goods" includes storing of the food and goods.

Marking of food and goods includes: 
(1) All food or goods which intended to be marked in accordance to Paragraphs 3 and 4 shall be made by affixing or annexing it to or with any other manner to mark it on or incorporate it with -

(a) The food or the goods themselves; or

(b) Anything in, on or with the food or goods are supplied.

(2) All services in relation to the food or goods which shall be intended to be marked in accordance to Paragraphs 3 and 4 shall be marked in any manner which may be considered as referring to the said service including in the premise where the service is provided."

Apart from that, in JAKIM's manual, there are some conditions in terms of use of halal certificate and halal logo. ${ }^{14}$ However, the halal logo is still being abused because of the poor enforcement of the existing laws. The failure to take proper actions against the misused halal logo puts the authority in question. ${ }^{15}$ As a consequence, Muslim consumers are saying enforcement of this law is inadequate and unsatisfactory to curb the problems of abuse of halal logo and halal certificate.

\section{THE VALUE OF HALAL LABEL FOOD}

Belief controls all human conducts including consumption of food. Halal food is not only consumed by Muslims. There have been debates in which a number of customers may have the perception that a label is the assurance for the products' validity and safety; Muslims comprehend lies with the religion perception, whereas others are not thoughtful about halal label. However, current issue of halal logo is not merely within the territory of religion but it is a global issue. ${ }^{16}$ Muslims and non-Muslims are both careful about the halal

14 Halal Malaysia Official Portal, 'Malaysian Halal Certification Procedure Manual,' http://www.halal.gov.my/v4/index.php/my/garis-panduan/manual-prosedurpensijilan-halal-malaysia, accessed on 14 July 2016.

15 Rezai, Golnaz, Zainalabidin Mohamed \& Mad Nasir Shamsudin, 'Assessment of Consumers' Confidence on Halal Labelled Manufactured Food in Malaysia,' 3342.

16 Rezai, Golnaz, Zainalabidin Mohamed \& Mad Nasir Shamsudin, 'Assessment of Consumers' Confidence on Halal Labelled Manufactured Food in Malaysia,' 3342. 
matter. ${ }^{17}$ In fact, non-Muslims are vigilant because this halal matter is a new business for them. Besides, the demands for halal label foods are growing as is the market for halal food.

\section{DILEMMA IN THE ENFORCEMENT OF HALAL LOGO}

Malaysian Muslims are living in a pluralistic society and they are very much attentive about their consumption of food. ${ }^{18}$ For that reason, the status of halal and haram is a prime concern to them. In reality, it is not possible to bear out a country's demand by their own deeds; for that reason, every country is depending on their export-import undertakings. Therefore, in the case of halal, it is very complex and it is not only restrained to pork-free substances only. To fulfill the Malaysian Muslims' demand, sometimes they import some food and products from non-Muslim countries and those halal statuses are also unknown to them since there are no uniform halal standards and halal logo for food processing or manufacturing. ${ }^{19}$ For instance, the use of genetically modified organism, such as non-halal gelatin in food is a big problem in this respect. ${ }^{20}$ Hence, halal logo plays an imperative role to ensure the acquiescence with Shariah law that certifies the halal-ness of a product and makes it lawful to the consumers. Certain cases, halal sign have been misused by some traders. The halal is used on the foodstuffs which have not been certified halal. Due to its

17 Danesh, Mir Mohammad Seyed, Alireza Chavosh \& Mehrzad Nahavandi, 'Notice of Retraction Comparative Analysis of the Muslims' and non-Muslims' Satisfaction with Halal Products,' in Advanced Management Science (ICAMS), 2010 IEEE International Conference, vol. 3 (2010), 317-319.

18 Ambali, A. R., \& Bakar, A. N. (2013). Halāl food and products in Malaysia: People's awareness and policy implications. Intellectual Discourse, 21(1).

19 Halim, Mustafa'Afifi Ab. \& Mohd Mahyeddin Mohd Salleh, 'The Possibility of Uniformity on Halal Standards in Organization of Islamic Countries (OIC) Country,' World Applied Sciences Journal, vol. 17/17 (2012): 6-10; Halim, Mustafa'Afifi Ab., Kamilah Wati Mohd, Mohd Mahyeddin Mohd Salleh, Asming Yalawae, Tuan Syed Mohd Najib Syed Omar, Asmidah Ahmad, Azlin Alisa Ahmad \& Mohd Izhar Ariff Mohd Kashim, 'Consumer Protection of Halal Products in Malaysia: A Literature Highlight,' Procedia-Social and Behavioral Sciences, vol. 121 (2014): 68-78.

20 Shah, Harmen \& Faridah Yusof, 'Gelatin As An Ingredient in Food and Pharmaceutical Products: An Islamic Perspective,' Advances in Environmental Biology, vol. 8 (2014): 774-780. 
commercial value, many traders are using fake halal logo and halal certificate in several business outlets. ${ }^{21}$

\section{HALAL LABELING AND MUSLIM CONSUMER DUTIES}

As Muslim consumers, they have two obligations regarding the purchase of food. One obligation is under the Latin principle of caveat emptor (buyer must be aware) and other is religious obligation. Caveat emptor imposes a responsibility to buy anything with verification that is irrespective of religion. However, under the Shariah principle, its Muslim consumer's inherent duties to look for halal food for consumption as well as the usage and check the status of the ingredients of the food. ${ }^{22}$ Though there is an authoritative body that is responsible for checking and monitoring the halal status. Therefore, labeling is an important matter and from the labeling, one may get the idea of the food's status. It is acknowledged that in case of food products, observation must be given more attentively.

However, at present time, there are many products available in the market and due to the complexity of tracing the source of various ingredients of food or drinks or other goods for consumption are made from halal sources or not. Many ingredients are written in their scientific nomenclature. ${ }^{23}$ Because of that, the scientific terms are not easily to be understood by the consumers. Alongside, another important matter Muslim consumers should be concerned with is the quality of the foodstuffs. In this regard, the Prophet Muhammad SAW has also emphasized in many of his hadiths. Even the guidelines provided by the Prophet Muhammad SAW showed that Islam puts great emphasis on as for the quality of food (tayyib), it is very important to pay serious attention to matters concerning halal and haram, and that one must try to avoid any food or drink which lies within the grey area and does not fall clearly under the halal or non-halal category consumed by its believers.

According to the hadith from Prophet Muhammad SAW:

21 Omar, Che Mohd Zulkifli Che, 'Challenges and Marketing Strategies of Halal Products in Malaysia,' Interdisciplinary Journal of Research in Business, vol. 3 (2013): 12.

22 Sawari, Siti Salwa Md, Mohd Al'Ikhsan Ghazali, Siti Mariam Abu Bakar Yap \& Adibah Abdul Latif, 'E-Halal as Method and Apparatus for Halal Product Detection in Malaysia,' Mediterranean Journal of Social Sciences, vol. 6/5 (2015): 638.

23 Kuswandi, B., D. Futra \& L. Y. Heng, 'Nanosensors for the Detection of Food Contaminants,' in Nanotechnology Applications in Food (2017), 307-333. 


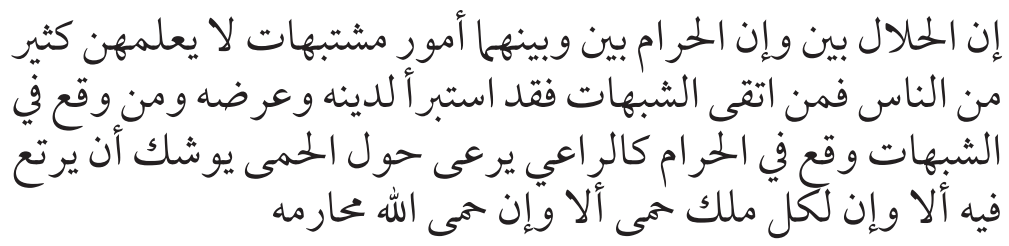

"What is halal is clear and what is haram is clear. Midway between them are mushtabihāt which many people do not know whether they are halal or haram. He who keeps away from them will protect his religion and will be saved. He who approaches them will be very near to haram, like a herdsman wandering near Hima (the place set by the king to be used by his cattle only), who could soon fall into this protected area. Surely for every king, there is such a protected area and God's is what He declared forbidden." 24

Therefore, from this abovementioned hadith, it is clear that between halal and haram there is that which is suspected (shubhah), things that must be avoided by the Muslims. ${ }^{25}$ Food and products become suspected when a person cannot identify whether the food or products are halal or haram. If there are no specific principles in this respect then a person should apply his or her own prudence to make the decision. So in that case, the food or products must be avoided. It is the duty of the Muslim consumers to examine the food and products properly before consuming or using them. At this juncture, halal logo plays an important role to find out the halal foodstuffs for Muslim consumers. They rely on the halal logo and halal certificate. Besides, in all aspects, Muslim consumers should be cautious in purchasing their halal products to fulfil their religious obligations.

\section{CASE STUDY OF MISUSE OF HALAL LOGO AND ABUSE OF HALAL CERTIFICATE}

The halal certificate and halal logo in Malaysia are issued by JAKIM and State Islamic Religious Council. Additionally, the halal logo and halal certificate

\footnotetext{
24 Abī 'Abd Allāh Muhammad Ibn Ismā'il al-Bukhārī, Șahīh al-Bukhārī (Riyād: Dār al-Salām, 1999), no. hadìth 2051; Abī al-Husayn Muslim Ibn al-Hajjāj Ibn Muslim al-Qushayrī al-Naysabūrī, Șaḥ̄h Muslim (Bayrūt: Dār al-Fikr, 1981), no. hadìth 1599.

25 'Definition of Halal,' http://ocw.ump.edu.my/pluginfile.php/9731/mod_resource/ content/ 1/CHAPTER\%20TWO.pdf', accessed on 14 July 2016.
} 
must be authorized and issued by a trustworthy Islamic organization in order to prevent any fraud and the use of fake and misleader of halal logo and halal certificate.

Recently, a great number of companies have been found to use either fake halal logo or logo that did not comply with the prescription given by competent authorities. As a result, consumers are getting more anxious and are beginning to question the credibility of the halal enforcement authorities. Some of the reported cases can be seen in Table 1:

\section{Table 1: Cases}

\begin{tabular}{|c|c|c|c|c|c|}
\hline No. & Date & Place & Complaint & Facts in Brief & Authority \\
\hline 1. & $\begin{array}{l}7^{\text {th }} \text { February } \\
2014\end{array}$ & $\begin{array}{l}\text { Bukit } \\
\text { Mertajam }\end{array}$ & $\begin{array}{l}\text { Halal logo } \\
\text { issued by } \\
\text { private } \\
\text { parties }\end{array}$ & $\begin{array}{l}\text { Enforcement officer } \\
\text { of JAKIM raided a } \\
\text { refinery fish processing } \\
\text { factory where they used } \\
\text { a halal logo issued by } \\
\text { private parties. }\end{array}$ & JAKIM \\
\hline 2. & $\begin{array}{l}5^{\text {th }} \text { February } \\
2014\end{array}$ & $\begin{array}{l}\text { Bukit } \\
\text { Mertajam }\end{array}$ & $\begin{array}{l}\text { Fake halal } \\
\log 0\end{array}$ & $\begin{array}{l}\text { An enforcement } \\
\text { officer raided a } \\
\text { fish ball processing } \\
\text { factory where they } \\
\text { used a halal logo not } \\
\text { recognized by the } \\
\text { Islamic Development } \\
\text { Department of Malaysia } \\
\text { (JAKIM). }\end{array}$ & $\begin{array}{c}\text { Officer of the } \\
\text { Domestic Trade, } \\
\text { Cooperatives and } \\
\text { Consumerism } \\
\text { Ministry }\end{array}$ \\
\hline 3. & $\begin{array}{l}3^{\text {rd }} \text { March } \\
2014\end{array}$ & Kota Bharu & $\begin{array}{l}\text { Fake halal } \\
\text { logo }\end{array}$ & $\begin{array}{l}\text { Officers raided a factory } \\
\text { and seized various types } \\
\text { of detergent worth about } \\
\text { RM } 12,000 \text { because they } \\
\text { did not carry the valid } \\
\text { halal logo. Moreover, } \\
\text { the halal logo license of } \\
\text { the factory had expired } \\
\text { in January } 2012 \text {. }\end{array}$ & $\begin{array}{l}\text { The Kelantan } \\
\text { office of the } \\
\text { Domestic Trade, } \\
\text { Cooperatives } \\
\text { and Consumer } \\
\text { Ministry }\end{array}$ \\
\hline 4. & $\begin{array}{l}7^{\text {th }} \text { March } \\
2014\end{array}$ & Melaka & $\begin{array}{l}\text { Fake halal } \\
\text { logo }\end{array}$ & $\begin{array}{l}\text { A local company that } \\
\text { produces health and } \\
\text { beauty beverage has } \\
\text { been found to use three } \\
\text { invalid logo certificates } \\
\text { on its products. }\end{array}$ & $\begin{array}{c}\text { Officer of the } \\
\text { Domestic Trade, } \\
\text { Cooperatives and } \\
\text { Consumerism } \\
\text { Ministry }\end{array}$ \\
\hline
\end{tabular}




\begin{tabular}{|c|c|c|c|c|c|}
\hline No. & Date & Place & Complaint & Facts in Brief & Authority \\
\hline 5. & $\begin{array}{l}11^{\text {th }} \text { April } \\
2014\end{array}$ & Johor & $\begin{array}{l}\text { Does not } \\
\text { have halal } \\
\text { logo }\end{array}$ & $\begin{array}{l}\text { Some religious } \\
\text { individuals found some } \\
\text { restaurants that do not } \\
\text { have the halal logo. } \\
\text { They also narrated that } \\
\text { these restaurants never } \\
\text { applied for halal logo } \\
\text { for the purpose of use. }\end{array}$ & $\begin{array}{c}\text { Majlis Agama } \\
\text { Islam Negeri Johor } \\
\text { (MAIJ) }\end{array}$ \\
\hline 6. & $\begin{array}{l}28^{\text {th }} \text { May } \\
2014\end{array}$ & Shah Alam & $\begin{array}{l}\text { Finding } \\
\text { non-halal } \\
\text { substance }\end{array}$ & $\begin{array}{l}\text { Cadbury Dairy Milk } \\
\text { Roast Almond which } \\
\text { has had its halal } \\
\text { certification tested } \\
\text { positive for traces of } \\
\text { porcine }\end{array}$ & Health Ministry \\
\hline 7. & $\begin{array}{l}4^{\text {th }} \\
\text { November } \\
2014\end{array}$ & Batu Caves & $\begin{array}{l}\text { Misuse of } \\
\text { halal logo }\end{array}$ & $\begin{array}{l}\text { PPIM found that } \\
\text { mineral water bottlers } \\
\text { Chuan Sin Sdn Bhd } \\
\text { used the image of Lord } \\
\text { Murugan, a Hindu deity, } \\
\text { on its labels together } \\
\text { with halal logo. This } \\
\text { is gross violation of } \\
\text { the Trade Description } \\
\text { (Certification and } \\
\text { Marking of 'Halal') } \\
\text { Order, 2011. }\end{array}$ & $\begin{array}{c}\text { Muslim } \\
\text { Consumers } \\
\text { Association of } \\
\text { Malaysia (PPIM) }\end{array}$ \\
\hline 8. & $\begin{array}{l}30^{\text {th }} \text { July } \\
2013\end{array}$ & $\begin{array}{l}\text { Kuala } \\
\text { Lumpur }\end{array}$ & $\begin{array}{l}\text { Misuse of } \\
\text { halal logo }\end{array}$ & $\begin{array}{l}\text { Identified between } 20- \\
30 \text {, products where } \\
\text { distributors who are no- } \\
\text { Muslims were involved } \\
\text { in the misuse of halal } \\
\text { logo. }\end{array}$ & $\begin{array}{l}\text { Malaysian } \\
\text { Consumer } \\
\text { Protection } \\
\text { Association }\end{array}$ \\
\hline 9. & $1^{\text {st July } 2012}$ & Shah Alam & $\begin{array}{l}\text { Failure to } \\
\text { display } \\
\text { halal logo } \\
\text { and halal } \\
\text { certificate }\end{array}$ & $\begin{array}{l}\text { Conducted a large-scale } \\
\text { operation to see whether } \\
\text { the food premises there } \\
\text { have obtained halal } \\
\text { certificate and halal } \\
\text { logo. They found that } \\
\text { some food premises } \\
\text { failed to display halal } \\
\text { certificate and halal } \\
\text { logo. }\end{array}$ & $\begin{array}{c}\text { Malaysian Islamic } \\
\text { Development } \\
\text { Department } \\
\text { (JAKIM) }\end{array}$ \\
\hline
\end{tabular}




\begin{tabular}{|c|c|c|c|c|c|}
\hline No. & Date & Place & Complaint & Facts in Brief & Authority \\
\hline 10. & $\begin{array}{l}2^{\text {nd }} \text { April } \\
2012\end{array}$ & $\begin{array}{l}\text { Kuala } \\
\text { Lumpur }\end{array}$ & $\begin{array}{l}\text { Misuse of } \\
\text { halal logo }\end{array}$ & $\begin{array}{l}\text { Found that supermarket } \\
\text { sells meat products from } \\
\text { a local company that } \\
\text { does not have halal logo } \\
\text { but the company claims } \\
\text { that it has just obtained } \\
\text { halal certification from } \\
\text { JAKIM. }\end{array}$ & $\begin{array}{l}\text { Assistant Director } \\
\text { of JAKIM }\end{array}$ \\
\hline 11. & $\begin{array}{l}17^{\text {th }} \text { February } \\
2012\end{array}$ & $\begin{array}{l}\text { Kuala } \\
\text { Lumpur }\end{array}$ & $\begin{array}{l}\text { Misuse of } \\
\text { halal logo }\end{array}$ & $\begin{array}{l}\text { Raided commercial } \\
\text { premise of food and } \\
\text { found to misuse the } \\
\text { halal logo. }\end{array}$ & $\begin{array}{l}\text { Malaysian } \\
\text { Consumer } \\
\text { Protection } \\
\text { Association }\end{array}$ \\
\hline
\end{tabular}

Sources: The Edge, Utusan Malaysia, Business Time, Blis, via IIUM Library, http://www.lib.iium.edu.my/index.jsp?module=ROOT\&action=onlinedb.jsp

The abovementioned cases have caused confusion among Muslim consumers. As a result, the consumers are more cautious in trusting the Malaysian halal logo. For that reason, Muslim consumers have started the practice of reading the products' label prior to their purchase. In certain cases, some manufacturers are using their own halal logo which is prohibited under the TDA 2011.

\section{SUITS FILED IN THE CASE OF ABUSE OF HALAL LOGO AND HALAL CERTIFICATE}

From the above-mentioned cases on abuse of halal logo and halal certificate, it is evident that violation of the Trade Description (Definition of 'Halal') Order, 2011, the Trade Description (Certification and Marking of 'Halal') Order, 2011 and the TDA, 2011 has randomly occurred in Malaysia. Between September 2011 to September 2015, the enforcement divisions of MDTCC and JAKIM have filed 120 cases on abuse of halal logo. Out of this 120 cases 64 cases are almost settled and the rest 56 pending jurisdiction. ${ }^{26}$ The nature and the offences are shown in Table 2:

26 Othman Nawang (Deputy Director, Enforcement Division, Ministry of Domestic Trade, Cooperatives and Consumerism), in interview with author, 5 October 2015. 
Table 2: The Nature and Offences

\begin{tabular}{|c|c|c|c|}
\hline $\begin{array}{c}\text { Name of the Act/ } \\
\text { Order }\end{array}$ & $\begin{array}{l}\text { Specific } \\
\text { Sections }\end{array}$ & Nature of the Offence & Punishment \\
\hline $\begin{array}{l}\text { The Trade } \\
\text { Description } \\
\text { (Definition of } \\
\text { 'Halal') Order, } \\
2011\end{array}$ & Section 3 & $\begin{array}{l}\text { Offences related to } \\
\text { contamination of food } \\
\text { and goods by any parts of } \\
\text { prohibited animal, alcoholic, } \\
\text { poisonous, hazardous, } \\
\text { impure elements and halal } \\
\text { services, halal food and goods } \\
\text { preparation, processing or } \\
\text { storage are associated with } \\
\text { prohibited groups of people } \\
\text { according to Hukum Syarak } \\
\text { and fatwa. }\end{array}$ & $\begin{array}{l}\text { Fined not more than } \\
\text { RM5 million and RM1 } \\
\text { million for corporate } \\
\text { and non-corporate } \\
\text { body respectively or } \\
\text { imprisonment not } \\
\text { exceeding three years } \\
\text { or both. }\end{array}$ \\
\hline $\begin{array}{l}\text { The Trade } \\
\text { Description } \\
\text { (Certification and } \\
\text { Marking of 'Halal') } \\
\text { Order, } 2011\end{array}$ & $\begin{array}{l}\text { Sections } 3 \\
\text { and } 4\end{array}$ & $\begin{array}{l}\text { Offences related to food, } \\
\text { goods and services supplied } \\
\text { by Muslims as well as } \\
\text { non-Muslims (intended to } \\
\text { be described in any other } \\
\text { manner to indicating halal) } \\
\text { not containing halal logo by } \\
\text { competent authorities. } \\
\text { And offences related to } \\
\text { imported food or goods not } \\
\text { marked with halal or certified } \\
\text { as halal by the foreign } \\
\text { halal certification body as } \\
\text { recognized by JAKIM }\end{array}$ & $\begin{array}{l}\text { Fined not more than } \\
\text { RM250000 and } \\
\text { RM100000 for person } \\
\text { from incorporate } \\
\text { and non-incorporate } \\
\text { bodies respectively, or } \\
\text { imprisonment not more } \\
\text { than three years or both. }\end{array}$ \\
\hline $\begin{array}{l}\text { The Trade } \\
\text { Description Act, } \\
2011\end{array}$ & Section 29 & $\begin{array}{l}\text { Offences related to violation } \\
\text { of ministerial order for } \\
\text { securing halal certificate, } \\
\text { marks and trade description. }\end{array}$ & $\begin{array}{l}\text { Fine not more than } \\
\text { RM200000 and } \\
\text { RM100000 for person } \\
\text { from incorporate } \\
\text { and non-incorporate } \\
\text { bodies respectively, or } \\
\text { imprisonment not more } \\
\text { than three years or both. }\end{array}$ \\
\hline
\end{tabular}

In summary, the abovementioned cases were filed on the following grounds:

i) Industry or company using the halal logo without halal certificate or using the halal logo that was not approved by JAKIM. 
ii) Described as halal without halal Malaysia.

iii) Mixed halal and non-halal substance under the TDO.

However, in the case of the abuse of halal logo, several types of problems have occurred i.e. the use of expired or overdue halal compliance certificate or companies that have never applied halal certificates or instead using forged halal certificate, which was alarming (suits filed are at the initial stage). ${ }^{27}$ Until now there is no progress for the abovementioned cases.

\section{LAWS IMPOSING CRIMINAL LIABILITIES FOR ABUSE OF HALAL LOGO AND HALAL CERTIFICATE}

Though Malaysia has a majority of Muslim population, halal issue is a pertinent matter to be tackled very carefully. Laws and regulations on halal were drafted and amended several times to ensure the protection and interests of Muslim consumers for their growing awareness and enhanced demand of halal food. ${ }^{28}$ There are numerous statutes that are in action together in dealing with a definite act in relation to the abuse of halal logo and halal certificate. The main objective of those laws is to ensure that certain requirements are fulfilled by the manufacturers, producers, sellers and distributors, which mean that all activities should be conducted in accordance with the laws and regulations. This is to protect the Muslim consumers from buying food with false or misleading information concerning the quality, standard and genuineness of the product. As per the laws concerning halal marking and halal certification, it imposes the criminal liability in terms of the abuse of halal logo and halal certificate. The following are laws in this regards,

Firstly, under Section 16 of the TDA, 2011, no person shall make any false representation by any means, whether direct or indirect, that any goods or services supplied by him/her or any methods adopted by him/her are of a kind supplied to or approved by any person including a government or government department or agency or any international body or agency whether in Malaysia or abroad and prohibiting or restricting the use of any name, emblem, insignia, seal, title, sign, words or letters or any other form of description in the course of

27 Mohd. Amri (Assistant Director, Halal Hub Division), in interview with author, 13 February 2015.

28 Yuhanis, A. A., \& Chok, N., 'The Role of Halal Awareness, Halal Certification, and Marketing Components in Determining Halal Purchase Intention Among Non-Muslims In Malaysia: A Structural Equation Modeling Approach,' Journal of International Food \& Agribusiness Marketing, vol. 25/1 (2013): 1-23. 
trade, business or profession. So, any person or company who contrivance the abovementioned provisions is considered to be committing an offence under Section 21 of the said Act and shall be liable to the following punishment:

"(a) if the person is a body corporate, shall be punished with fine not exceeding five hundred thousand ringgit and for every second or subsequent offence shall be liable to a fine of one million ringgit; or

(b) if the person is not a body corporate, shall be punished with a fine not exceeding two hundred and fifty thousand ringgit or with imprisonment for a term of not more than three years and for every second or subsequent offence and for maximum penalty of five hundred thousand ringgit or imprisonment of not more than five years or both"

On the other hand, according to Section 29 of the TDA 2011, any person who in the course of any trade or business certifies, marks, supplies or offers to supply goods of that description in contravention of the order commits an offence and shall be liable to the following punishment:

"(a) if the person is a body corporate, shall be punished with fine not exceeding two hundred it and for every second or subsequent offence shall be liable to a fine of five hundred thousand ringgit; or

(b) if the person is not a body corporate, shall be punished with a fine not exceeding one hundred thousand ringgit or with imprisonment for a term of not more than three years and for every second or subsequent offence and for maximum penalty of two hundred and fifty thousand ringgit or imprisonment of not more than five years or both".

Each and every imitation of halal logo and halal certificate is prohibited by the abovementioned provisions and is considered a punishable offence. In other words, the use of any halal certification and halal logo, for instance, JAKIM's halal logo is subjected to be used as per the laws and regulations in Malaysia. Any person intending to use halal certification and halal logo must ensure the products or services are lawfully halal certified and authorized to be used.

However, there are cases that violate Section 16 of TDA, 2011. In examining the cases related to the abuse of halal logo, it can be concluded that general 
practice of using JAKIM's halal logo by the accused by displaying it on the wrapping of the products, banner, and bunting and in their advertisement. For example, there are several cases against food court operators where they purposely displayed JAKIM's halal logo at the counter and signboard of the restaurant or on their menu. In the event that anybody that makes or produces a false representation of the logo under section 16 , he or she commits an offence under Section 21 of the same Act.

Furthermore, Section 5 and 7 of the Trade Description (Definition of 'Halal') Order 2011 state as follows:

"Any person who supplies or offers to supply any food, goods or service in relation to the food or goods which are described as 'halal' or any other expression which is not in compliance with this Order shall be guilty of an offence".

And shall be liable-

"(a) if such person is a body corporate, to a fine not exceeding five million ringgit and for a second or subsequent offence to a fine not exceeding ten million ringgit; or

(b) if such person is not a body corporate, to a fine not exceeding one million ringgit or to imprisonment for a term not exceeding three years or to both and for a second or subsequent offence to a fine not exceeding five million ringgit or to imprisonment for a term not exceeding five years or both".

In another cases food court, restaurant and hotel operators take the opportunity during the fasting month (Ramadan) to attract Muslim consumers. They offer several packages such as Ramadan buffet. In Malaysia, the 'Ramadan Buffet' itself is considered as a halal meal. In several occasions, the investigation agencies have discovered that the accused used raw material such as non-halal chicken, apparatus, ketchup and other ingredients to prepare their food. The raw materials were also kept with liquor and other unknown ingredients. Actually, the accused merely used halal logo to attract Muslim consumers during the fasting month.

Secondly, abusing the halal certificate and misusing the halal logo are also offences under Section 8 of the Trade Descriptions (Certification and Marking of 'Halal') Order 2011.

"Any person who supplies or offers to supply any food, goods or service in relation to the food or goods which deem to be in contrary to this Order shall be liable and upon conviction - 
(a) if the person is an incorporated body, shall be punished with a fine not exceeding two hundred and fifty thousand ringgit and for every second or subsequent offence shall be liable to a fine of five hundred thousand ringgit; or

(b) if the person is not a body corporate, shall be punished with a fine not exceeding one hundred thousand ringgit or with imprisonment for a term of not more than three years and for every second or subsequent offence and for maximum penalty of two hundred and fifty thousand ringgit or imprisonment of not more than five years or both".

Under the Trade Description (Certification and Marking of Halal) Order 2011, only JAKIM and the States Islamic Religious Council are the competent authorities to certify any goods, food, or services in relation to halal status in accordance with the TDA 2011. For imported goods, only certain foreign bodies recognized by JAKIM are allowed. The lists of foreign bodies are as specified under the regulation. In fact, only certification from JAKIM, States Religious Council and specified foreign bodies recognized by JAKIM shall be valid to be used in case of halal logo and certificate. In this regard one more sample case was taken under Section 2(3) of the Trade Descriptions (Certification and Marking of Halal) Order 2011. A company was inspected and taken enforcement action due to a complaint made by JAKIM. The company committed an offence because, as a non-competent authority defined in the order, it issued a certificate of halal to other company. The company acted as a competent authority by giving services on inspection, consultation and certification, which is an offence under the order. Most of the clients are from local food manufacturers, caterers and other business.

In Malaysia, the Muslims believe depend on the fact that buyers and sellers should provide halal food and products for their regular consumption. ${ }^{29}$ The main intention of displaying the halal label on food products is to assist Muslim consumers to choose their food products for their consumption without any fear. This guarantees that the food products must not come from prohibited sources and that is imperative not only to fulfill their needs but also to give them peace of mind. However, the earlier discussion showed that the issue of halal still needs proper monitoring and consciousness to completely fulfill the

29 Ambali, Abdul Raufu \& Ahmad Naqiyuddin Bakar, 'People's Awareness on Halal Foods and Products: Potential Issues for Policy-Makers,' 3-25. 
demands of the Muslims, not only in Malaysia but also around the world as the Malaysian halal certification is acknowledged all over the world. ${ }^{30}$

\section{CONCLUSION}

Legal development is a continuing process. Malaysian halal laws are no exception. Similarly in other developing countries, it's monitoring and execution procedures needs more improvement. Moreover, with the nonexistence of global halal standard, halal logo and lack of international consensus are the main obstacles to developing the halal certification in the national and international jurisdiction. The main function of the halal logo is to assist the Muslim consumers to select the food products without any doubt or hesitation. If the product holds a recognized halal label, it may be considered a quality product by the buyers. Commonly, the halal label, sign or mark ensures the conformity of halal of the product and Muslims rely heavily on the making of halal products in case of the decision to buy their food products.

As consumers are not in a position to accurately assess halal monitoring, they rely on the food manufacturing industry and government to build the confidence for them. And in the case of Malaysia, the authorities are responsible for certifying halal food products; as most of the Muslim consumers characteristically purchase food products that have the word 'halal' on the package. Furthermore, in Malaysia, several statutes are in operation to regulate halal issues, in particular with the law imposing criminal liabilities on the violation of halal logo. In fact, the Malaysian laws are the most stringent in the world in terms of regulations of halal matter. Henceforth, some policy actions need to be established as the governance of halal by the government of Malaysia.

Although the legislation made by the government would eliminate the problem of fake halal logo and halal certificates from unreliable sources policy mechanisms are needed to secure the confidence of Muslim in certifying products with several legislation in place for the protection of consumers in terms of halal food and products. In addition to this matter, the attention of the policy-makers have to be increased to a point as breeders, slaughterhouses, certifying agencies, retailers, consumers, and religious representatives in most cases have different stakes and viewpoints on halal production and processing, which may jeopardize the economic potential of the halal market in the future.

30 Asa, R. S., 'Malaysian Halal Certification: It's Religious Significance and Economic Value,' Jurnal Syariah, vol. 25/1 (2017): 137-156. 
Moreover, having examined all the provisions of halal laws, it is easy to find out the lacunae of the implementation of laws in the sense that the whole provisions are deemed to be insufficient to govern all matters relating to the violation of halal if the authorities do not widen their monitoring and executing power. It gives an impression that the present laws are only to facilitate local or global food trade in Malaysia, which reflects the inadequacy in helping Muslims in gaining trust with halal products. Beside all these, the execution of laws has to be upsurge together with monitoring headway before the using of halal logo and after getting the halal certificate.

\section{REFERENCES}

Abī 'Abd Allāh Muḥammad Ibn Ismā'il al-Bukhārī, Ṣaḥīh al-Bukhārī (Riyād: Dār al-Salām, 1999).

Ab̄̄ al-Ḥusayn Muslim Ibn al-Hajjāj Ibn Muslim al-Qushayrī al-Naysabūrī, Șaḥịh Muslim (Bayrūt: Dār al-Fikr, 1981).

Ambali, Abdul Raufu \& Ahmad Naqiyuddin Bakar, 'Halal Food and Products in Malaysia: People's Awareness and Policy Implications,' Intellectual Discourse, vol. 21/1 (2013): 7-32.

Ambali, Abdul Raufu \& Ahmad Naqiyuddin Bakar, 'People's Awareness on Halal Foods and Products: Potential Issues for Policy-Makers,' Procedia-Social and Behavioral Sciences, vol. 121 (2014): 3-25.

Asa, R. S., 'Malaysian Halal Certification: It's Religious Significance and Economic Value,' Jurnal Syariah, vol. 25/1 (2017): 137-156.

Borzooei, Mahdi \& Maryam Asgari, 'The Evolution of Halal from A Religious Symbol to A Brand,' Czech Journal of Social Sciences, Business and Economics, vol. 3/1 (2014): 48-56.

Danesh, Mir Mohammad Seyed, Alireza Chavosh \& Mehrzad Nahavandi, 'Notice of Retraction Comparative Analysis of the Muslims' and nonMuslims' Satisfaction with Halal Products,' in Advanced Management Science (ICAMS), 2010 IEEE International Conference, vol. 3 (2010), 317-319.

Halal Malaysia Official Portal, 'Halal History,' http://www.halal.gov.my, accessed on 12 August 2016.

Halim, Mustafa'Afifi Ab. \& Mohd Mahyeddin Mohd Salleh, 'The Possibility of Uniformity on Halal Standards in Organization of Islamic Countries (OIC) Country,' World Applied Sciences Journal, vol. 17/17 (2012): 6-10. 
Halim, Mustafa'Afifi Ab., Kamilah Wati Mohd, Mohd Mahyeddin Mohd Salleh, Asming Yalawae, Tuan Syed Mohd Najib Syed Omar, Asmidah Ahmad, Azlin Alisa Ahmad \& Mohd Izhar Ariff Mohd Kashim, 'Consumer Protection of Halal Products in Malaysia: A Literature Highlight,' Procedia-Social and Behavioral Sciences, vol. 121 (2014): 68-78.

Jamal, Ahmad \& Juwaidah Sharifuddin, 'Perceived Value and Perceived Usefulness of Halal Labeling: The Role of Religion and Culture,' Journal of Business Research, vol. 68/5 (2015): 933-941.

Kuswandi, B., D. Futra \& L. Y. Heng, 'Nanosensors for the Detection of Food Contaminants,' in Nanotechnology Applications in Food (2017), 307333.

Halal Malaysia Official Portal, 'Malaysian Halal Certification Procedure Manual,' http://www.halal.gov.my/v4/index.php/my/garis-panduan/ manual-prosedur-pensijilan-halal-malaysia, accessed on 14 July 2016.

Malkawi, Bashar H., 'Food Labeling and Halal Mark,' Intellectual Property Rights: Open Access (2014).

Market Watch, 'The Malaysian Food Industry,' http:/www.malaysia.ahk. de/fileadmin/ahk_malaysia /Market_reports/The_Malaysian_Food_ Industry.pdf, accessed on 30 August 2016.

Mathew, Vloreen Nity, 'Acceptance on Halal Food among Non-Muslim Consumers,' Procedia-Social and Behavioral Sciences, vol. 121 (2014): 262-271.

Omar, Che Mohd Zulkifli Che, 'Challenges and Marketing Strategies of Halal Products in Malaysia,' Interdisciplinary Journal of Research in Business, vol. 3 (2013): 11-17.

Rezai, Golnaz, Zainalabidin Mohamed \& Mad Nasir Shamsudin, 'Assessment of Consumers' Confidence on Halal Labelled Manufactured Food in Malaysia,' Pertanika Journal of Social Science \& Humanity, vol. 20/1 (2012): 33-42.

Sawari, Siti Salwa Md, Mohd Al'Ikhsan Ghazali, Siti Mariam Abu Bakar Yap \& Adibah Abdul Latif, 'E-Halal as Method and Apparatus for Halal Product Detection in Malaysia,' Mediterranean Journal of Social Sciences, vol. 6/5 (2015): 638-642.

Shah, Harmen \& Faridah Yusof, 'Gelatin As An Ingredient in Food and Pharmaceutical Products: An Islamic Perspective,' Advances in Environmental Biology, vol. 8 (2014): 774-780.

Tieman, Marco, 'Establishing the Principles in Halal Logistics,' Journal of Emerging Economies and Islamic Research, vol. 1/1 (2013): 1-13. 
Yuhanis, A. A., \& Chok, N., 'The Role of Halal Awareness, Halal Certification, and Marketing Components in Determining Halal Purchase Intention Among Non-Muslims In Malaysia: A Structural Equation Modeling Approach,' Journal of International Food \& Agribusiness Marketing, vol. 25/1 (2013): 1-23.

\section{Interviews}

Mohd. Amri (Assistant Director, Halal Hub Division), in interview with author, 13 February 2015.

Othman Nawang (Deputy Director, Enforcement Division, Ministry of Domestic Trade, Cooperatives and Consumerism), in interview with author, 5 October 2015.

\section{Statutes}

The Malaysian Halal Certification Procedure Manual, 2014 (Malay.)

Trade Description (Certification and Marking of Halal) Order 2011 (Malay.)

Trade Description Act 1972 (Malay.)

Trade Description Act 2011(Malay.) 
Jurnal Syariah, Jil. 27, Bil. 2 (2019) 367-388 